\title{
Media "Prezi Presentation Software" based in Learning Language Skills at University
}

\author{
Biya Ebi Praheto ${ }^{1}$, Octavian Muning Sayekti ${ }^{2}$ \\ 1biya.ebi@ustjogja.ac.id, 2sayekti.octavian@gmail.com \\ Universitas Sarjanawiyata Tamansiswa, Yogyakarta, Indonesia
}

\begin{abstract}
This research has purpose to develop a medium of learning Indonesian language skills "Prezi Presentation Software" based. Learning Indonesian language skills is categorized as difficult learning Learning media at this time is influenced by the advancement of technological developments. Therefore, the development of learning media more emphasizes on computer-based media. One of them is the use of presentation software prezi, in purpose to develop the medium of learning Indonesian language skills in universities, especially in Primary School Teacher Education Departments. This prezi presentation software is a software whichis used to make internet-based presentations. The material which is developed using this software includes four aspects of skills, namely listening, speaking, reading and writing skills. Each skill material aspect is developed in each individual prezi file. Media presentation Indonesian language skills which are prezibased developed using themes or interesting templates including various elements such as text, images, video, backsound, music and animation. In addition, the color selection is also considered to make learning media more interesting. Learning media "Prezi Presentation Software" based is expected can improve the quality of the learning process and motivate students to learn, so that learning outcomes can be improved and learning objectives can be achieved optimally.
\end{abstract}

Keywords: Learning Media, Prezi Presentation Software, Indonesian language skills, listening, speaking, reading, writing

\section{Introduction}

The media has an important role in learningthe process. The media also improve the quality, motivation and student's interest in learning. In addition, the purpose of learning media become a tool for learning. Helping the communication process between the teacherand the student, and an assistance tool for teaching materials to be better received by the student[1]. Learning media always develops in line with the development of sophisticated technology. Today, the media is not only in the form of conventional media such as two-dimensional and three-dimensional media, but also the learning media has been computer-based with various software programs which can be used in its creation. With presence of the technology in learning, teaching with Technology based is able to involve students with various stimulationwhich involved in activity-based learning[2].

This case also affects to the Indonesian language learning process skills in universities. Indonesian language skills courses not only appear in the Indonesian language educational program, but also in the Primary School Teacher Education Department. It registered as a basis for teaching skills for prospective teachers who have never been separated from Indonesian language as the instruction language. In learning Indonesian language skills, students are not only required to understand the material cognitively, but also practically means skilled $\mathrm{Ni}$ using language. Moreover, there are four aspects which students must skillfully, namely listening, speaking, reading and writing skills. However, the learning media for learning Indonesian language skillis still limit, the teacher only uses power points and learning media which still text based. This caseresists the students to understand learning 
material. So far, it has impacted to students' lack motivation and the less interest in learning so that cause low learning outcomes.

Responding to that case, it is necessary to develop the interesting and innovative learning media so that it will help the teacher in delivering learning material and helps students to understand the learning material. As explained that the learning media always develops in line to technological advances, then in the development of learning media for Indonesian language skills, especially in the Primary School Teacher Education Departmentmust be computerbased. Some software which can be utilized to make learning media is quite a lot such as Adobe Flash and Macromedia Flash. However, in using the software it is required a special skills so that not all teachers are able to use it. One of the software which is quite interesting and easy to use is Prezi Presentation Software.As explained also that along with the rapid development of science and technology, the learning media became very varied. One of them is using Prezi Software as an innovative learning media based on information and communication technology. The trainingto use Software Prezi is a new breakthrough in learning. Where is the Prezi Software a software which is used for internet-based presentations. Besides it used to presentations, prezi can also be used as a tool to explore and share ideas on virtual canvas. Prezi became superior because this program uses Zooming User Interface (ZUI) which allows the users to zoom in and zoom outon their presentation media. Prezi is used to make presentations in both linear and non-linear forms, namely structured presentations as examples of linear presentations, or mind-map presentations as the examples of non-linear presentations. On prezi, text, images, videos, and other presentation media are placed on the presentation canvas and it can be grouped into the frames provided. The users can build a predetermined percentage navigation pathin purpose to make linear presentations[3].

Some previous studies which related to the development of prezi-based learning media, such as research which were carried out by Özcan Erkan Akgün et al who examined the effects of learning which using powerpoint presentations compared with prezi software on cognitive abilities in drawing conclusions and conceptual learning[4]. Other research was also conducted by Amaal Al Masri et al with the purpose of researchis the effects of using a prezi presentation to teach English sounds to elementary students and whether this new technology could facilitate students' ability in English[5]. In addition, Sabra Brock and Cornelia Brodahl also researched the use of the prize which compares to the Cross-cultural in Learning Prezi Presentation Software in the US and Norway[6]. Another study was also conducted by Aljehani who explained the use of presentation software prezi to improve student vocabulary learning skill[7].

Relate to the importance of learning media in learning Indonesian language skills. Then it is necessary to develop a computer technology-based learning media to be in accordance with the existing technological developments. The choice of presentation software is due to the process of making and using the software easily so that it does not make it difficult for teachers and students to use it. In addition, Fox et al in his study stated that students preferred to use prezi as a presentation tool because it easier to use and enjoyable for its users[8].

\section{Method}

The method which is used in this research is library Research. The research is the part of the research procedure for developing Indonesian language learning media skills based on Prize presentation software. Library research is a series of activities which related to library data collection methods[9]. Furthermore, library research is a research which uses the methods to obtain information data by using the facilities in the library, such as books, magazines, 
documents, historical stories[10]. Data were analyzed using qualitative descriptive. The data analysis consists of three activities which occur simultaneously, namely data reduction, data presentation, and drawing conclusion or verification[11].

\section{Discussion}

It is common whichthe learning in the present cannot be separated from the presentation media as a medium whichmaximize the learning process. In this case, the basic difference in prezi presentation program with power point program is the interface, if the power point is one page one screen, then in prezi software one screen loads the entire page and can be zoomed per page according to the user's interestin whereverpagewhich the user wants. Prezi can be accessed online or offline, but if accessed via offline there will be some inaccessible menus such as entering music. Moreover, the Prezi application combines creative thinking with modern technology facilities, leading into interactive presentations and highly customizable presentations, as well as structured such as mind maps[12]. Indonesian language skills material in Primary School Teacher Education Department consists of four aspects which developed in technology-based media with presentation software prezi.

The first is the aspect of speaking.In the prezi presentation, speaking aspects consist of some material speaking skills such as the nature of speech, the purpose of speaking, the principle of speaking, the function of speaking, determinants of speaking, types of speaking, examples of speaking skill, storytelling, speaking, interviewing, debating, and panel discussion. In the prezi media the speaking skills developed not only the theory but also appearing the examples in the videos form. It is intended that students' understanding is not only theoretically but also capable of speaking skillfully. The Prezipresentation speaking skills interface displayed below.

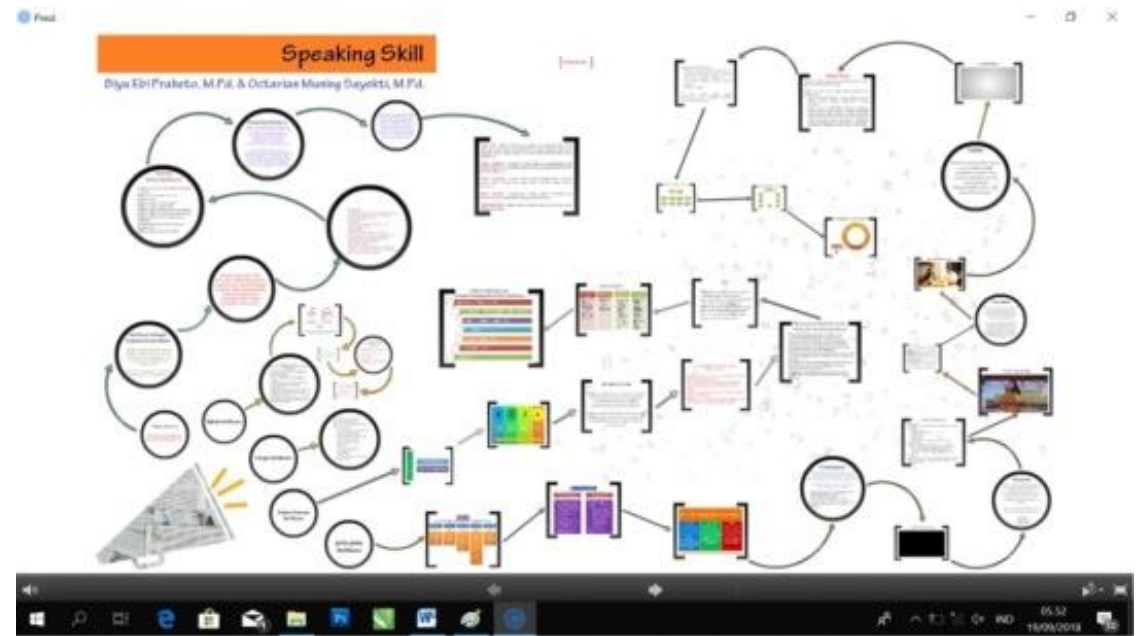

Figure 1. The Presentation of the Prize Speaking skills

In Figure 1, there is a canvas or a page that contains enough slides of material which can be zoomed adjustingas what the user's want. In addition, to focus the attention of the students, the mediawere also given an interesting back sound. If one page is selected then, enlarged it will look like such as image below. 


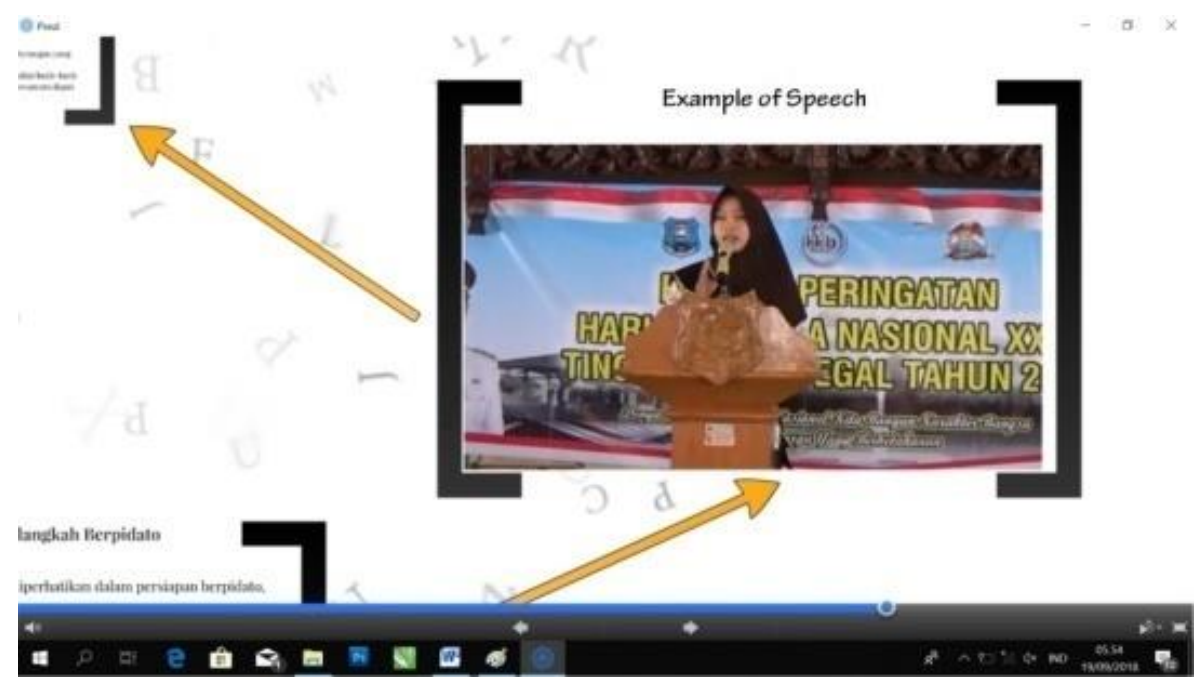

Figure 2. The Display the Prize Presentation if it is enlarged

Figure 2 shows when the user chooses to enlarge one part of the material,namely in the sample of video material when giving a speech. Besides, the user can enlarge the display according to the user will without any restrictions, because the screen on the prize presentation can be enlarged quite broadly.

Second, it is the listening aspect, in the listening aspect there are also various material in one prize presentation media. The material is the nature of listening, the role of listening, the purpose of listening, the listening process, the variety of listening, intensive listening, extensive listening, listening influencing factors, listening determinants, and listening techniques. The following presentation of prezi for listening skills.

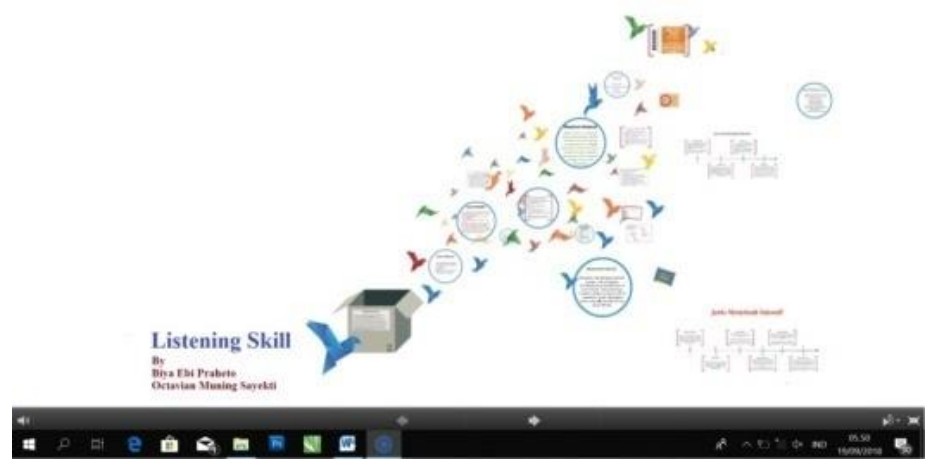

Figure 3. Listening Skills Prezi Presentation

It can be seen in figure 3, one page or prezi canvas can contains all the material which is displayed in an interesting template. The template selection also influences the attractiveness of users or students in learning so that it can help students to understand the material or help the teacherin delivering the material. 
Third, it is a reading skill.In reading skills there are also various material in one presentation. The material consists of the nature of reading, the purpose of reading, the reading function, the benefits of reading, the characteristics of a good reader, reading techniques, types of reading, intensive reading, extensive reading, and loud reading. The reading material not only presents theory but also presenter the video examples such as examples of reading the text techniques of the Proclamation and the 1945 Constitution, another examples isreading beautiful short stories and the example of reading beautiful poetry. Below, the following presentation of prezi reading skills.

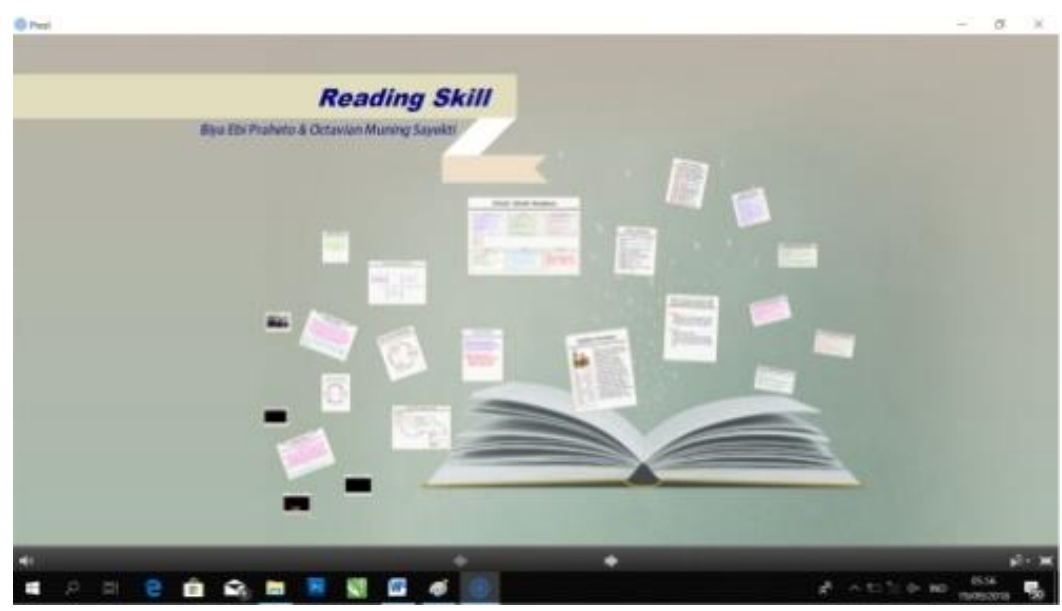

Figure 4. Prezi Presentation of Reading Skills

It can be seen in Figure 4 which the template is made according to the theme of the learning material, namely reading so that the teacher chooses a template with figured of books and the flying paper, each paper is densely enlarged and contains learning material. The selection of appropriate templates also affects the attractiveness of the learning media, especially those made through the prezi presentation software.

Fourth, the writing skill. Writing skills are the activities of composing and arranging sentences in such a way in purpose the messages, information, and intentions contained in the thoughts, ideas, and opinions of thewriter can be conveyed properly. In the presentation of the prezi writing skills there were several materials as material for students learning. The material includes the nature of writing, the writing function, the purpose of writing, the stages of writing, the variety of writing, continuous writing, essays and types of essays, essays and the role of the essay, the benefits of the writing framework, writing letters, types and forms of letters, writing announcements, writing poetry, writing short stories, and writing articles. Below, the following presentation of prezi writing skills. 


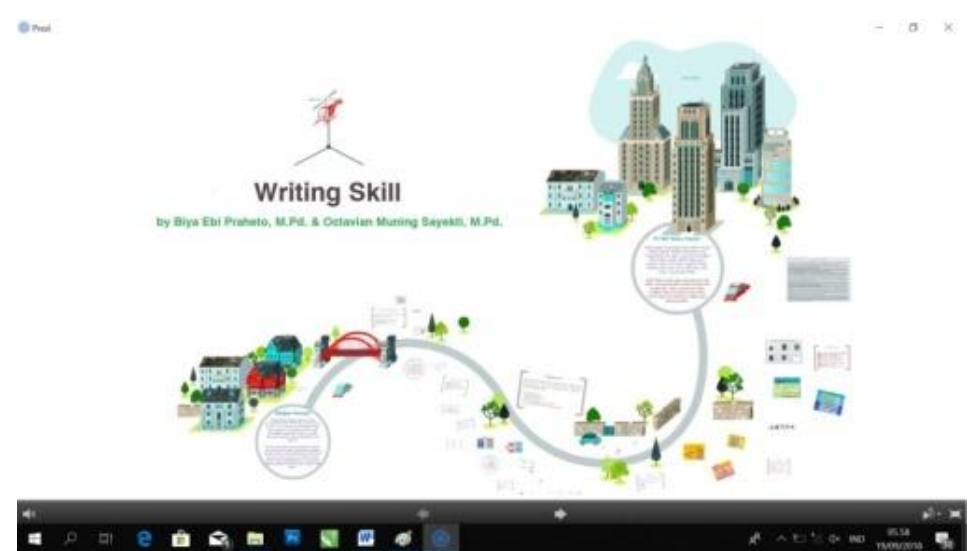

Figure 5.The presentation of Reading Skills Prize

Various display themes which can be made through the prezi presentation software. Itfigured in figure 5, the display of the presentation prezi writing skills. Besides, we be able to insertthe sounds, images or videos. One of the highlights of the prezi presentation is the user can insert the PDF file format without having to go through a menu link such as in a PowerPoint presentation. When inserting a file with pdf file format,the pdf will convert directly in jpg format as shown in the following figure 6.

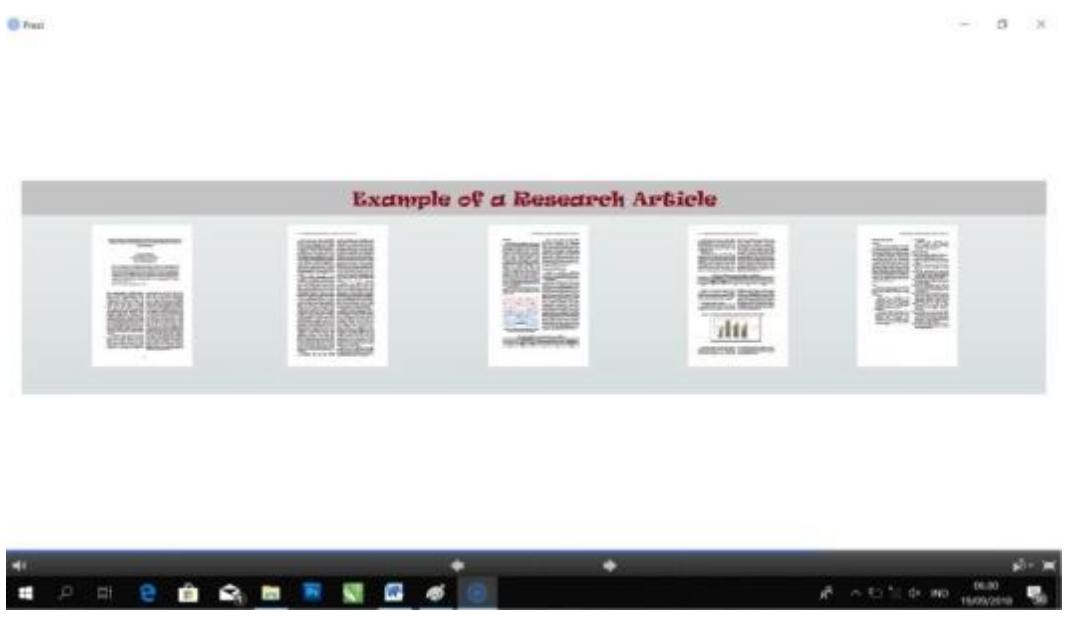

Figure 6. The display of PDF file format in Prezi presentation

In Figure 6, it displaysone of the writing materials is an example of a scientificarticle writing. The file directly is inserted in PDF file format then it will directly convert to JPG file format, which appears parallel in every page. The users can enlarge the appearance of each page so that it can be read clearly.

The development of language media skills especially in Indonesian language in universities usingprezi presentation software gives more advantages when compared with powerpoint. The use of prezi in universities and it is beneficial for student experience. Moreover, the major which is facilitated by Prezi can keep students' high interests and facilitate the student to understand of the linkages topic[13]. The prezi presentation has an appeal with various zoom 
capabilities and templates. In addition, if it is used for language skills material, it is very suitable because it is easy to use and it can load enough material in one template screen. Then, the prezi presentation is not only text based but alsocaninsert various files types such as images, animations, videos, sounds, pdf files, and so on. This case is suitable with the material of Indonesian language skills with four aspects which is studied such as listening, speaking, reading and writing skills and not only requires theoretical but also practical material. Same as that case, Prezi's advantage is the software can accommodate a variety of learning styles, because the prezi is programmed to display visually, audio and animation media[14]. Prezi presentation software is also a unique medium because there is a presentation in it which is very different from the presentation in general. Media prezi focuses on one slide field called virtual canvas. Then, the user can explore the canvas parts to the smallest part, so that the main concept to be conveyed is clearly visible. The use of ZUI facilities makes the presentation look dynamic, because the canvas can be reduced, enlarged, even rotated 360 degrees. Besides, the prezi is an Adobe Air-based application, so that video or flash animation can be run lighter than when using power points. The weakness of Prezi's is that it only uses ZUI technology with an enlarged display, so that this software looks monotonous. The installation process requires an internet connection. And it's hard to enter mathematical symbols.

Presentation media have an important role for Indonesian language learning in universities, with the adult age level of students, sometimes lecturer forget the learning media and assume students are able to receive learning material well. However, this is not the reality, in learning environment the learning media has an important role to improve the quality of learning processes and outcomes at any level of education, not least in universities. In addition, one factorwhich can influence the success of the learning process is the usage of learning media. Learning media has an important role in learning activities because it facilitates the lecturer to deliver material to students in learning activities[15].

\section{Conclusion}

The learning media of Indonesian language skills prezi presentation-based is more interesting than the power point media in general. Learning media based on presentation have an attractive appearance with one page or one canvas which containing all learning material and it can be enlarged in certain parts that you want to learn. The material developed in this learning media includes four aspects of Indonesian language skills such as listening, speaking, reading and writing skills. With the appropriate template and color selection, the prezi software can provide the presentation-based learning media more interesting. In addition, various elements are integrated into one unit in the learning media such as text, images, animation, video, backsound, and music. Another interesting thing is the prezi presentation software is able to insert files in pdf and doc file format directly and appear on the page without setting up a link to the related file. The development of learning media on Indonesian language skills prezi-based, it is hoped that it can trigger an impact in improving the learning quality and the learning outcomes which is achieved.

\section{Reference}

[1] Biya Ebi Praheto, "Penerapan Quantum Learning dengan Media Permainan Puzzle untuk Meningkatkan Kemampuan Membaca Aksara Jawa pada Siswa Kelas 3B SD Negeri 1 Wangon Kab. Banyumas," Sebelas Maret University, 2013.

[2] C. M. Khairnar, "Advance Pedagogy: Innovative Methods of Teaching and Learning," vol. 5, no. 11, 2015.

[3] Ari Suharjanto, "Penerapan Media Pembelajaran Dengan Penggunaan Software Prezi 
dalam Upaya Meningkatkan Minat Belajar Mata Diklat Komunikasi,” Sebelas Maret University, 2013.

[4] Ö. E. Akgün, A. Babur, and E. Albayrak, "Effects of Lectures with PowerPoint or Prezi Presentations on Cognitive Load, Recall, and Conceptual Learning," vol. 8, no. 3, pp. 1-11, 2016.

[5] A. Al Masri, A. M. Ismael, and F. Z. Qudah, "Teaching English sounds using prezi presentation at King Abdullah II school for excellence and its effect on students achievement," vol. 3, no. 1, pp. 82-88, 2015.

[6] S. Brock and C. Brodahl, "A Tale of Two Cultures : Cross Cultural Comparison in Learning the Prezi Presentation Software Tool in the US and Norway," vol. 12, 2013.

[7] W. M. A. Aljehani, "Using PREZI Presentation Software to Enhance Vocabulary Learning of EFL Secondary School Students," Educ. Res. Int., vol. 4, no. 4, pp. 67-81, 2015.

[8] H. Fox and R. Metcher, "Prezi versus powerpoint in the efl classroom 1," no. February, pp. 37-41, 2016.

[9] Mahmud, Metode Penelitian Pendidikan. Bandung: Pustaka Setia, 2011.

[10] Abdul Rahman Sholeh, Pendidikan Agama dan Pengembangn untuk Bangsa. Jakarta: PT. Raja Grafindo Persada, 2005.

[11] M. B. Miles and A. M. Huberman, Analisis Data Kualitatif. Jakarta: UI Press, 2014.

[12] A. Špernjak, "IS PREZI MORE USEFULLNESS EDUCATION TOOL THAN POWERPOINT ?,” vol. 1, pp. 191-195, 2014.

[13] N. Strasser, "Using Prezi In Higher Education,” vol. 11, no. 2, pp. 95-98, 2014.

[14] M. Y. Rodhi, "Pengembangan Media Pembelajara Berbasis Prezi untuk meningkatkan keterampilan Berpikir Kritis Pada Materi Kalor," J. Inov. Pendidik. Fis., vol. 3, no. 2, pp. 137-142, 2014.

[15] B. E. Praheto, M. Rohmadi, and N. E. Wardani, "Eligibility Multimedia Interactive Language Skills Learning for Primary School Teacher Education,” vol. 7, pp. 747$750,2018$. 